\title{
Determinants of The Firm Value in Indonesia
}

\author{
Marshelino Boyke Kristanto, Lodovicus Lasdi \\ Accounting Study Program, Universitas Katolik Widya Mandala Surabaya
}

Email: marshellino88@gmail.com

\section{A R T I C L E I N F O}

Received:

20 December 2020

Revised:

5 March 2021

Accepted:

13March 2021

\begin{abstract}
A B S T R A C T
Companies are no longer only faced with a single bottom line that centers on financial conditions, but companies must adjust to the triple bottom line concept. One form of environmental responsibility for corporate management for stakeholders and shareholders is by disclosing greenhouse gas emissions. Company value is also a very important factor because it can describe the business processes in a company. A high company value will provide a strong interest for investors to buy shares. An increase in stock prices will also increase the value of a company. This study aims to test and obtain empirical evidence regarding the effect of greenhouse gas disclosure, profitability and leverage on firm value. The population of this research is mining sector companies listed on the Indonesia Stock Exchange during the 2014-2018 period. The sample selection in the study using purposive sampling method. The data analysis technique used multiple linear regression. The results of this study indicate that the variable of greenhouse gas disclosure and profitability has a significant positive effect on firm value. The leverage variable does not have a significant effect on firm value, this is because the amount of debt held by the company is not a major concern for investors because investors are more concerned with how management uses the debt effectively and efficiently for use in developing the company.
\end{abstract}

Keywords: Greenhouse Gas Emissions, Profitability, Leverage

Cite this as: Kristanto, M. B., Lasdi, L. (2021). Determinants of The Firm Value in Indonesia. Wiga : Jurnal Penelitian Ilmu Ekonomi, 11(1), 63-74. https://doi.org/10.30741/wiga.v11i1.610

\section{INTRODUCTION}

In order to obtain future profits, investing is one method that is often used in today's modern era. Based on data taken from kominfo.go.id (2019) it is stated that the Investment Coordinating Board (BKPM) announced that data on investment realization for the first quarter of 2019 experienced an increase of $5.3 \%$ by Rp.195.1 trillion compared to the same quarter in 2018 only 185.3 trillion. Investors will see the company more deeply before investing. This makes the companies in the IDX (Indonesia Stock Exchange) strive to continue to improve their quality, 
where this is done so that the company's stock price has a high potential selling price and attracts the attention of investors. Dewi dan Abudanti (2019) state that the goals of each company are divided into 2, namely short-term goals that are useful for maximizing profits and minimizing expenses, while the long-term goal is to optimize the value of the company it self. Company value is something that needs to be considered because it is related to the survival of the company or can be called a going concern. The company was not created for a short period of time or was created, but is expected to be sustainable. When the company has a good performance it will also have an impact on the value of the company. The company value will be the benchmark in giving positive signals in the eyes of investors to invest their capital, while the creditors, the value of the company will be the benchmark in repaying the debt that has been borrowed. Funders will analyze the company's performance before investing, because an increase or decrease in the value of the company will have an impact on the welfare of the funders.

The purpose of forming the company is to shape the company's value to be better or there is a company development towards success. This development can be seen from the assessment of parties outside the company such as investors or creditors on the assets owned by the company or seen from the high share price of the company. The company's value can be defined as the market value because when the stock price rises will increase the profits given to the shareholders of the maximum. Firm value in this study is measured using price to book value (PBV). PBV will represent how high the market appreciates the book value of shares, so that PBV is very closely related to the stock price of a company. The higher the value in a company, it means that the company is able to have a stock market price above its book value, so the company will appear to have good operating performance and show that the prosperity of its investors can be achieved. Linawaty dan Ekadjaja (2017) states that the PBV ratio is used to state that the price of a share is overvalued or undervalued. When the PBV ratio is high, outsiders will increasingly believe in the company's prospects and PBV can illustrate the company's capability in increasing the company's value relative to the total invested capital (Riadi, 2017). PBV will be very useful for investors in creating investment strategies because the ups and downs of shares as measured by the PBV ratio will reflect the company's condition

In the increasingly advanced era of globalization, companies are not only facing challenges to achieve maximum financial conditions or what is commonly called a single bottom line, but now it has turned into a triple bottom line, that is companies are not only looking for profit. but a company must also have a positive impact on society and also actively contribute to preserving the environment. Nurdiawansyah (2017) argues that global warming is a problem that arises because of the large amount of greenhouse gases in the atmosphere, these gases will coat the earth and give the reflection of heat radiation back to the earth. Greenhouse gases are becoming increasingly over the normal limit due to the combustion of fossil fuels such as petroleum, gas and coal or other pollutants. There are several types of greenhouse gases such as methane (CH4), nitrous oxide (N2O), perfluorocarbons (PFCs), hydrofluorocarbons (HFCs), and carbon dioxide (CO2). The problem of overcoming global warming is an intensive problem currently being discussed in various parts of the world. One of the causes is greenhouse gases. In 2019 the earth experienced high temperature levels and undetectable weather, where the earth is currently experiencing the hottest record and experiencing an increase in carbon dioxide by forty-six percent Alfarizi (2019). Anggraeni (2015) states that disclosure of greenhouse gas emissions, namely past qualitative and quantitative data and forecasting forms of carbon emissions produced by companies, as well as statements and financial implications of companies in overcoming weather changes. The disclosure of greenhouse gas emissions is a form of the company's contribution to environmental changes caused by its activities. Anggraeni (2015) states that the disclosure of information by the company will increase the value of the company, because it shows that the company is responsible to the public. In other words, although the company contributes to the occurrence of greenhouse gases, the company is also trying to reduce this impact. Disclosure of greenhouse gas emissions can be proxied by using the measurement of the carbon emission 
disclosure index or it can be referred to as the Carbon Disclosure Project Checklist (Choi, dkk. 2013).

Ahmad dan Hossain (2015) state that the theory of legitimacy is a theory that reveals as a whole about voluntary environmental and social responsibility which is the basis of company incentives. This aims to promote honest disclosure so that it can be accepted by the community and provide a positive reciprocal impact, so that it requires a good correlation between the company's operations and the wishes of the community. Legitimacy is a matter that needs to be considered for companies, where legitimacy imposes limits on social values, norms, and observes the community's response to the impact that is given due to the company's operations. Companies that go public need to provide relevant information about social activities and their responsibilities in protecting the environment not only to shareholders, but other stakeholders such as the surrounding community and the government also need attention. This statement is also supported by Anggraeni (2015) who state that companies that make voluntary disclosures will have a positive impact and be able to improve the quality of their financial reporting, so that this will attract the attention of shareholders in investing in the company. The companies must realize that the use of natural resources has limits so that they must be managed effectively and efficiently which will also affect the sustainability of the company. When a company pays attention to matters that have a social or environmental impact, this will also have an impact on the value of the company . Anggraeni (2015) states that disclosure of greenhouse gas emissions has a positive effect on firm value. Anggraeni's research (2015) has a different opinion with Matsumura, Prakash, and Munoz (2014), which states that carbon emissions have a negative relationship to company value, where carbon emissions are a type of greenhouse gas. This research needs to be retested because the research is still inconsistent.

The most important goal in the company is to generate maximum profit so that the company can maintain its business continuity in the long term. An increase in profits not only affects the health of the company but also affects the condition of investors. Cecilia, Rambe, Torong (2015) argue that profitability is a representation of the company's success in carrying out its operating activities and is a benchmark for investors to invest their capital. Profitability in this study is measured using return on equity ( ROE) because this ratio calculates the company's ability to generate income for investors. When the ROE ratio in a company increases from year to year, it indicates that the company has a good chance in the future due to a continuous increase in net income. Conversely, if the ROE ratio has decreased, it means that the company has decreased in profit. With this ratio, it can make it easier for investors to determine the company because it shows the effectiveness and efficiency of the company in managing the resources carried out by the company's management. According to Munawaroh dan Priyadi (2014) signal theory describes companies to make disclosures so that investors can get the information needed. Sampurna dan Sari (2018) stated that in accordance with the theory, high profitability signals provide positive signals for investors, so that they have an impact on increasing company value. When the company's profitability increases, it will attract the attention of investors in investing their capital because the main objective of investors is to get dividends. Investors can carry out an analysis by looking at the profitability of a company before investing, because the effectiveness of the company can be measured through its profitability.

The company's ability to create profits is also a measure in maximizing firm value. Company managers must have broad insight in managing company income and expenses in order to reduce costs so that they can generate greater profits. Investors will take into account the value of the company before investing, this is related to profitability because the size of the profits is related to the company value. Rachmawati dan Pinem (2015) states that profitability is the level of profit a company receives when conducting operations. Companies need to pay attention to profitability in order to evaluate their effectiveness in managing an organization, therefore companies often create various strategies that are used to increase their profitability. A stable or consistent level of profitability will have an impact on the company in maintaining its business by getting more 
profits than the risks. Profitability can determine future prospects whether a company can continue its business or not. Companies must always make efforts to show increased profitability because when profitability is high, the sustainability of the company will also be guaranteed. Mandey, Pangemanan, and Pangerapan (2017) reveal that profitability has a positive effect on firm value, while according to Thaib and Dewantoro (2017), it is stated that profitability has a negative and insignificant effect on firm value. Given the differences in the results of these studies, this research is interesting to revisit.

In fulfilling operational needs or investing in the company, it can be done by going into debt. Leverage ratio is a ratio that calculates the level of the company that is financed by debt and how much is the company's capacity to pay off its debt which consists of the principal and interest (Sitanggang, 2014: 23). The measurement of leverage in this study is calculated using the debt to equity ratio by dividing the amount of debt with the capital held. Andriani (2017) state that this ratio can describe how much a company receives loans from creditors. Companies that get funding from large creditors will show a high level of debt to equity ratio, so this will cause the company to bear a high interest expense as well. According to Wijaya (2018), the debt to equity ratio is able to create information about the capital structure controlled by a company, therefore the risk level of uncollectible debt can be detected. Healy dan Palepu (2001) state that signal theory assumes that company managers have a broader insight into the condition of the company than outsiders, in other words, managers are more skilled at predicting company conditions in the future even in efficient market conditions. Prasetyorini (2013) states that leverage is very significant for investors in making decisions to invest because leverage in the company will affect the company's capability in returning to investors.

Septariani (2017) reveal that debt is one way for companies to get funding apart from investors to expand the company's expansion, where there will be a contractual agreement between debtors and creditors. In providing loans, creditors do not directly lend funds, but creditors will analyze the company's performance whether it has high corporate value. This is done by creditors so that they do not hesitate in providing loans, because if the company has a high corporate value it means that the company will pay back its obligations in accordance with the agreed amount and time. The existence of this leverage ratio will function as a measure of the capability of a company in paying off all its debts, both long and short term. Investors reject companies with large leverage ratios and will prefer companies with small leverage ratios because the assets owned by the company are larger than the debt they have. If the leverage ratio of a large company, then the company tends to pay debts not on time according to the specified date because the company's debt is greater than its assets. However, investors can also accept companies that have large leverage ratios or debt owned by large companies because they think that high debt can be used in developing their business to be bigger so that they can get higher returns. According to Sutama and Lisa (2018), leverage has a significant positive effect on firm value, while according to Sari and Abudanti (2014) leverage has a negative effect on firm value. The results of previous studies Sutama dan Lisa (2018) dan (Sari dan Abundanti, 2014) regarding the effect of leverage on firm value are still inconsistent, so this research is interesting to do. The samples in this study were taken from mining sector companies listed on the Indonesia Stock Exchange because one of the main factors causing greenhouse gas emissions is the combustion system of fossil fuels such as petroleum, coal, gas, and the like.

In gaining positive attention from the public, the company has implemented various strategies, one of which is the disclosure of useful information to realize investor desires. Gabrielle dan Toly (2019) states that companies that disclose information related to the environment will show transparency, reduce uncertainty, and provide a competitive advantage. Conversely, if the company discloses little or no disclosure, it will create many risks, such as litigation risk, penalties for pollution, future environmental costs, and low future cash flows. Saka dan Oshika (2014) state that there is a positive stock market reaction when companies make additional disclosures regarding quality sustainability reports. This disclosure indicates that the company 
cares about the state of the world regarding the environment and has tried to minimize it. Previous research has shown that greenhouse gas emissions have a positive effect on firm value (Saka dan Oshika, 2014). This research indicates that outsiders provide a good assessment for the company for management's efforts to disclose greenhouse gas emissions. From this explanation, the following hypothesis can be formulated. H1: The disclosure of greenhouse gas emissions has a positive effect on firm value.

Profitability is a representation of the company's capability in carrying out its operational activities to generate profits during the period so that it can achieve the sustainability of the company Tanjung (2019). Cecilia, dkk. (2015) states that profitability is the level of net income generated by a company through its operating activities. In other words, when the level of profit generated by a company is high, the ability to distribute dividends is undoubtedly more. When the company's profitability increases, it will attract investors' attention in investing their capital because the main objective of investors is to get dividends. Investors can carry out an analysis by looking at the profitability of a company before investing, because the effectiveness of a company can be measured through its profitability. When the company has a large profit, it will attract many investors to buy the company's shares, so that the stock price will automatically increase. The increase in share price is what makes the company value also increase. Research Tanjung (2019) agrees with Putra and Lestari's research (2016) which found that profitability has a positive effect on firm value. From this explanation, the following hypothesis can be formulated. H2: Profitability has a positive effect on firm value.

Leverage can encourage companies to obtain high profits by utilizing leverage as capital and assets, so that when there is an increase in profits it will also affect the welfare of investors and increase the value of the company. Chandra dan Djajadikerta (2017) states that leverage is very significant for investors in making decisions to invest because leverage in the company will affect the company's capability in returning to investors Rizqia, Aisjah, and Sumiati (2013) stated that leverage has a positive effect on firm value. In other words, an increase in debt will make shareholders see positive future prospects because this can provide opportunities for the company to develop. So that shareholders also have the opportunity to obtain a greater return on investment without having to cut the proportion of ownership in the company. The opinion of Rizqia, et al. This is in line with the results of Wijaya's research (2018) which states that leverage has a significant positive effect on firm value. From this explanation, the following hypothesis can be formulated. H3: Leverage has a positive effect on firm value.

\section{METHOD}

This study uses a quantitative research design, namely a research approach that uses numbers as data in the statistical testing process. The purpose of the hypothesis in this study is to analyze and test the disclosure of greenhouse gas emissions, profitability, and leverage on the value of companies in mining companies listed on the Indonesia Stock Exchange (IDX). The research analysis period is five years, namely 2014 - 2018. The 2014-2018 period in this research is used to update the research period and as additional empirical evidence of environmental problems that exist in Indonesia.

The operational definition along with the measurements of each variable are as follows: Greenhouse gas emissions is an action that has the aim of calculating how much a company produces emissions and as a reference in minimizing these emissions. Disclosure of gas emissions greenhouse in this study was measured through a checklist that has been developed by Choi, dkk. (2013) that carbon disclosure project. Companies are given a score of 1 if they disclose the criteria from the checklist and will be given a score of 0 if they do not disclose the criteria. Choi, dkk. (2013) states that the total score obtained will be calculated using the following formula : PEGRK $=($ Total items disclosed in period $\mathrm{t}) / 18 \times 100 \%$ 
Profitability in this study is measured by return on equity, which is a ratio data scale that compares the amount of net income with the company's equity. Return on equity can be formulated as follows: Return on equity = (Income after taxes and interest) $/$ (Total Equity). Leverage in this study is measured by a debt to equity ratio that compares the company's total debt to the company's equity. The debt to equity ratio is formulated as follows: LEV = (Total Liability) / (Total Equity). The company value in the current study is measured by price to book value (PBV) which compares the stock market price with the stock book value. The price to book value is formulated as follows: PBV = (Market Price per Share) / (Book Value per Share). Where the market price per share is obtained from the average share price five days after the date of publication of the financial statements and the book value per share is obtained through the following formula: Book Value Per Share = (Total Equity) / (Outstanding Share).

This study uses the type of quantitative data obtained from the annual reports of mining companies that are listed on the Indonesia Stock Exchange (IDX) for the 2014-2018 period. Sources of financial report data are obtained through the IDX website (www.idx.co.id) and the official yahoo finance website. All data used are secondary data. The data collection method used in this research is by means of documentation. Documentation is carried out by compiling annual reports of mining companies listed on the IDX for the 2014-2018 period and the company's share price is obtained through the official yahoo finance website.

This study uses mining companies listed on the IDX as the study population. Sampling of the population using method purposive sampling with the following standards mining companies listed on the IDX for five years namely 2014-2018, companies that have had positive profits for five years, namely 2014-2018, mining companies that disclose greenhouse gas emissions at least one disclosure item related to greenhouse gas emissions, and companies that have information related to research variables (greenhouse gas emission disclosure, profitability, leverage, firm value).

The data analysis technique used in this study is multiple linear regression analysis. The following is a multiple linear regression equation model used to analyze the hypothesis: $\mathrm{PBV}=\mathrm{a}+$ $\mathrm{b}_{1}$ PEGRK $+\mathrm{b}_{2}$ ROE $+\mathrm{b}_{3}$ DER $+e$, Information: PBV $=$ Firm Value, $\mathrm{a}=$ Constant, $\mathrm{b}=$ Model regression coefficient, PEGRK $=$ Greenhouse Gas Emission Disclosure, ROE = Profitability, DER $=$ Leverage, $e=$ error .

\section{RESULTS AND DISCUSSION}

Based on the predetermined criteria, there were 15 companies with the number of observations for 5 years so that they had a total of 75 samples. In sampling, it can be explained that 1) there are 12 mining sector companies that do not present complete annual reports, namely from 2014-2018, 2) there are 19 mining sector companies that do not have positive profits in a row, namely from 20142018 , 3) in the mining sector sampling during the 2014-2018 period, it was found that all companies disclosed greenhouse gas emissions at least one disclosure item related to greenhouse gas emissions, 4) there were 3 companies that did not have information related to research variables because they did not publish market price per share which is part of the calculation of price to book value.

The data used in this study are firm value (PBV), disclosure of greenhouse gas emissions (PEGRK), profitability (ROE), and leverage (DER). The results of descriptive statistics can be seen in table 1 
Table 1. Descriptive Statistics Results

\begin{tabular}{lccccc}
\hline & N & Minimum & Maximum & Mean & Std. Deviation \\
\hline LOG_PBV & 75 & $-1,36$ & 0,63 & $-0,2183$ & 0,46417 \\
LOG_PEGRK & 75 & $-0,78$ & $-0,08$ & $-0,4993$ & 0,20103 \\
ROE & 75 & 0,00073 & 0,55252 & 0,1478974 & 0,12762777 \\
DER & 75 & 0,16940 & 3,56140 & 0,9054219 & 0,66871475 \\
\hline
\end{tabular}

Source: Data processed (2019)

Table 1 provides information on the minimum value, maximum value, mean, and standard deviation of the firm value, disclosure of greenhouse gas emissions, profitability, and leverage. The following is an explanation of each variable used: The highest company value is 0,63 owned by Baramulti Suksessarana Tbk (BSSR) in 2014. While the lowest company value was $-1,36$ owned by Ratu Prabu Energi Tbk (ARTI) in 2018. The average value of the firm value variable is 0,2183 , this shows that the company as a whole has a PBV of less than 1 or the average company has a market price that is much smaller than the book value of the company's shares. The standard deviation of the company value is 0,46417 , this indicates that the company still has a fairly wide range of data distribution variations because the standard deviation has a value that is higher than the average value even though it is almost close to the average value.

The highest greenhouse gas emission disclosure value was $-0,08$ owned by Timah Tbk (TINS) in 2016 and 2018. Meanwhile, the lowest greenhouse gas emission disclosure value was -0,78 owned by Surya Esa Perkasa Tbk (ESSA) in 2014-2018, J Resources Asia Pasifik Tbk (PSAB) in 2014 and 2015, Baramulti Suksessarana Tbk (BSSR) in 2014, and Mitrabara Adiperdana Tbk (MBAP) in 2014. The average value of greenhouse gas emission disclosures was $-0,4993$. It can be concluded that the average company only disclosed 4 to 6 items of the 18 items Carbon Disclosure Project Checklist. The standard deviation is 0,20103 , this shows that the variable of greenhouse gas emissions has a fairly wide data distribution because the standard deviation has a higher value than the average value.

The highest profitability value was 0,55252 owned by Baramulti Suksessarana Tbk (BSSR) in 2017. While the lowest profitability value was 0,00073 owned by Surya Esa Perkasa (ESSA) in 2016. The average profitability value was 0,1478974 , it can be concluded that on average the company earned a profit of $14.78 \%$ during the $2014-2018$ period. The standard deviation value is 0,12762777 , with this it can be seen that the standard deviation is lower than the average value. Therefore it can be concluded that the data used in the profitability variable has a data distribution that is not so wide with a coefficient of variation of 1,159 obtained from 0,1478974 / 0,12762777.

The highest leverage value was 3,56140 owned by Citatah Tbk (CTTH) in 2014. Meanwhile, Resource Alam Indonesia Tbk (KKGI) had the lowest leverage value in 2016 amounting to 0,16940 . The average value of leverage is 0,9054219 , this indicates that the average company uses debt in carrying out its operating activities compared to using its own capital. The standard deviation value is 0,66871475 , with this it can be seen that the standard deviation is lower than the average value. Therefore it can be concluded that the data used in the leverage variable has a data distribution that is not so wide with a coefficient of variation of 0,739 obtained from 0,9054219 / 0,66871475 .

This research wants to test classic assumptions based on BLUE (Best Linear Unbias Estimator). The BLUE assumption can represent an unbiased result of the data used. To believe that the regression model obtained has the ability to predict, this research model has met the underlying requirements, namely with normally distributed data and no multicollinearity, heteroscedasticity, and autocorrelation. 
Table 2. Determination Coefficient Test

\begin{tabular}{cccc}
\hline $\mathbf{R}$ & R Square & $\begin{array}{c}\text { Adjusted } \boldsymbol{R} \\
\text { Square }\end{array}$ & Std Error of the Estimate \\
\hline 0.563 & 0.317 & 0.288 & 0.39158 \\
\hline
\end{tabular}

Source: Data processed (2019)

The test results of the coefficient of determination in table 2 show that the adjusted $\mathrm{R}$ square is 0,288 , so it can be concluded that the independent variable (disclosure of greenhouse gas emissions, profitability and leverage) can equalize the dependent variable (firm value) of 0,288 or $28,8 \%$, so that it is equal to $71,2 \%$ is explained by other variables not present in the current study.

Table 3. Statistical Test $\mathbf{F}$

\begin{tabular}{cc}
\hline F & Significance \\
\hline 10,994 & 0,000 \\
\hline
\end{tabular}

Source: Data processed (2019)

The results of the F statistical test in table 3 show a significance value of $F$ of 0,000 . This shows that the regression model in testing the hypothesis of the effect of disclosure of greenhouse gas emissions, profitability, and leverage on firm value is feasible because it has a significance value of $\mathrm{F}$ less than 0,05 .

Table 4. $\mathrm{t}$ test

\begin{tabular}{lccccc}
\hline \multirow{2}{*}{ Variable } & \multicolumn{2}{c}{$\begin{array}{c}\text { Unstandardized } \\
\text { coefficient }\end{array}$} & t & sig & Information \\
\cline { 2 - 4 } & B & Std Error & & & \\
\hline (Constant) & $-0,282$ & 0,142 & $-1,992$ & 0,050 & \\
PEGRK & 0,712 & 0,243 & 2,931 & 0,005 & Hypothesis accepted, Positive \\
ROE & 1,908 & 0,375 & 5,088 & 0,000 & Hypothesis accepted, Positive \\
DER & 0,152 & 0,077 & 1,982 & 0.051 & The hypothesis is rejected \\
\hline
\end{tabular}

Source: Data processed (2019)

The variable of disclosure of greenhouse gas emissions (PEGRK) shows a t value of $+2,931$ with a significance level of 0,005 which is less than 0,05 , so it can be concluded that PEGRK has a significant positive effect on PBV. Therefore, $\mathrm{H} 1$ which states that the disclosure of greenhouse gas emissions has a positive effect on firm value is accepted. The profitability variable (ROE) shows a $t$ value of $+5,088$ with a significance level of 0,000 which is less than 0,05 , so it can be concluded that ROE has a significant positive effect on PBV. Therefore, $\mathrm{H} 2$ which states that profitability has a positive effect on firm value is accepted. The leverage variable (DER) shows a $t$ value of $+1,982$ with a significance level of 0,051 which is greater than 0,05 , so it can be concluded that DER has no significant effect on PBV. Therefore, H3 which states that leverage has a positive effect on firm value is rejected.

The first hypothesis shows that the disclosure of greenhouse gas emissions has a positive effect on firm value. This hypothesis confirms the test results that the disclosure of greenhouse gas emissions has a significant positive effect on firm value, so it can be stated that the first hypothesis (H1) is accepted. The first hypothesis has confirmed the theory of legitimacy, because carrying out the disclosure of greenhouse gas emissions indicates that the company is willing to be responsible and minimize the negative impacts that have been given. With actions that show the company's concern for the surrounding environment, people will be able to accept the products produced by the company. The existence of this disclosure will also open and raise a level of public awareness of the importance of protecting the environment and minimizing environmental problems that are 
increasing. This hypothesis has also confirmed signal theory, the existence of signals given by the company will make investors more accurate and wise in making decisions. With environmental symptoms such as global warming, one of which is the main cause of greenhouse gas emissions, indirectly, it will be a significant responsibility for investors to interact with companies that produce greenhouse gas emissions. In providing this signal, investors will be able to put more pressure on companies to behave honestly in producing the emissions that have been created and encourage the company's seriousness in overcoming the problem of greenhouse gas emissions.

The disclosure of greenhouse gas emissions has a positive effect on company value because when a company makes disclosures related to the environment, it indicates that the company cares and is responsible for the condition of the environment around it. This hypothesis confirms the three previous studies, namely that conducted by Anggraeni (2015) which states that disclosure of greenhouse gas emissions has a positive effect on firm value, the second is Olayinka and Maninda dan Agustia (2017) which state that environmental disclosure has positive influence on firm value, where the disclosure of greenhouse gas emissions is included in environmental disclosures, and the last research conducted by Saka dan Oshika (2014) which shows that greenhouse gas emissions have a positive effect on firm value. This indicates that the more companies make disclosures, the higher the value of the company.

The second hypothesis reveals that profitability has a positive effect on firm value. This hypothesis confirms the test results that profitability has a significant positive effect on firm value, so it can be stated that the second hypothesis $\left(\mathrm{H}_{2}\right)$ is accepted. The second hypothesis has confirmed the signal theory, where when a company has a high level of profitability it is a good signal for investors. This is the right time for investors to invest their capital because the company is experiencing profits. The profit the company gets will reflect the success of the company itself because it is in line with its goals. This will also strengthen the company in competition and in maintaining its business in the long term. With the signal given by the company, it will be easier for investors to analyze a company. The profitability generated by the company is an important signal for its shareholders because profitability can reflect how much effectiveness it is in managing a company. Therefore, an increase in profitability can increase the selling value of the company in attracting investors to invest their capital. The increase in profitability will be in line with the reduction in risk received by the company.

This hypothesis confirms the three previous studies, namely research conducted by Mandey, et al. (2017) which reveals that profitability has a positive influence on firm value, the second is Tanjung (2019) which reveals that profitability has an influence on firm value, and the last research conducted by Putra and Lestari (2016) which found that profitability has an influence positive on company value. This provides evidence that an increase in profitability will represent the success of a company so that it will also increase the company's image. The third hypothesis reveals that leverage has a positive effect on firm value. This hypothesis is rejected because the test results show that leverage has no significant effect on firm value, so it can be stated that the third hypothesis $\left(\mathrm{H}_{3}\right)$ is rejected. The third hypothesis has confirmed the signal theory, which proves that an increase or decrease in debt does not have an impact on firm value because in making decisions investors do not see the level of debt of a company as a consideration in investing its capital. The level of debt owned by the company is not a major problem for investors if the composition of debt owned by the company is still in a reasonable condition or amount.

This hypothesis confirms the three previous studies, namely research conducted by Ogolmagai (2013) which states that leverage has no significant effect on firm value, the second is Novari and Lestari (2016) which revealed that leverage has no effect on firm value, and the last one is Nugroho. and Abdani (2017) which states that leverage has no effect on firm value. This indicates that the size of the debt owned by the company is not a major concern for investors because investors see more about how management can use this capital effectively and efficiently to be used in developing the company. 


\section{CONCLUSION}

Based on the results of the analysis and discussion of the effect of disclosure of greenhouse gas emissions, profitability and leverage on company value in mining sector companies listed on the Indonesia Stock Exchange for the period 2014-2018, it can be concluded that disclosure of greenhouse gas emissions and profitability has a significant positive effect on value company. Companies that disclose greenhouse gas emissions will have a positive effect on company value because disclosure of greenhouse gas emissions will make shareholders and stakeholders consider that the company does not only disclose the consequences of its business activities, but this shows that there is a sense of corporate responsibility. to the environment. This will increase the value of the company because the company proves that there is a triple bottom line concept that does not only focus on the profit-seeking side and measures of social care, but also concerns the environment by trying to minimize it. This research shows company that have higher profitability will give an impact on firm value because profitability will represent the operating activities of a company during one period. The increased profitability of the company will be in line with the increase in the value of a company because when the company experiences positive profits it will symbolize good performance and will attract the attention of investors in investing their capital. Leverage has no significant effect on firm value. This indicates that the size of the debt owned by the company does not affect the value of the company. Shareholders are more concerned with information on the use of the debt, whether it is distributed effectively and efficiently. With a company that can manage its debt optimally, it will be in line with the objectives of shareholders, namely to obtain large returns on the profits generated by the company.

\section{REFERENCE}

Ahmad, N. N. N., dan Hossain, D. M. (2015). Climate change and global warming discourses and disclosures in the corporate annual report: a study on the malaysian companies. ProcediaSocial and Behavioral Sciences, 172, 246-253.

Alfarizi, M. K. (2019). Hari bumi 2019: temperatur tinggi dan cuaca semakin liar. Https://Tekno.Tempo.Co/Read/1198387/Hari-Bumi-2019-Temperatur-Tinggi-Dan-CuacaSemakin-Liar/Full\&view=ok, 10 September 2019, Pukul 02.30 WIB.

Andriani, D. (2017). Pengaruh kebijakan dividen dan leverage terhadap nilai perusahaan dengan profitabilitas sebagai pemoderasi. (Skripsi, Program Sarjana Universitas Katolik Widya Mandala Surabaya, Surabaya, Indonesia), Didapat dari http://repository.wima.ac.id/13823/.

Anggraeni, D. Y. (2015). Pengungkapan emisi gas rumah kaca, kinerja lingkungan, dan nilai perusahaan. Jurnal Akuntansi Dan Keuangan Indonesia, 12(2), 188-209.

Cahya, B. T. (2016). Carbon emission disclosure: ditinjau dari media exposure, kinerja lingkungan, dan karakteristik perusahaan go public berbasis syariah di indonesia. Nizham Journal of Islamic Studies, 5(2), 170-188.

Cecilia., Rambe, S., dan Torong, M. Z. B. (2015). Analisis pengaruh corporate social responsibility, profitabilitas, dan ukuran perusahaan terhadap nilai perusahaan pada perusahaan perkebunan yang go public di indonesia, malaysia, dan singapura. Simposium Nasional Akuntansi, 18(46).

Chandra, H., dan Djajadikerta, H. (2017). Pengaruh intellectual capital, profitabilitas, dan leverage terhadap nilai perusahaan pada perusahaan sektor properti, real estate, dan konstruksi bangunan yang terdaftar di bursa efek indonesia. Ultima Accounting, 9(2), 1-14.

Choi, B. B., Lee, D., dan Psaros, J. (2013). An analysis of australian company carbon emission disclosures. Pasific Accounting Review, 25(1), 58-79.

Dewi, N. P. I. K., dan Abudanti, N. (2019). Pengaruh leverage dan ukuran perusahaan terhadap nilai perusahaan dengan profitabilitas sebagai variabel mediasi. E Jurnal Manajemen, 8(5), 3028-3056. 
Gabrielle, dan Toly, A. A. (2019). The effect of greenhouse gas emissions disclosures and environmental performance on firm value. Jurnal Ilmiah Akuntansi Dan Bisnis, 14(1), 106119.

Healy, P. M., dan Palepu .K.G. (2001). Information asymmetry, corporate disclosure, and the capital markets : a review of the empiricial disclosure literature. Journal of Accounting and Economics, 31(1-3), 405-440.

Kementerian Komunikasi dan Informatika Republik Indonesia. (2019). Perkembangan realisasi investasi. Https://Kominfo.Go.Id/Index.Php/Content/Detail/18391/Investasi-Triwulan-iTahun-2019-Naik-53-Mencapai-Rp-1951-Triliun/0/Artikel_gpr.

Linawaty, dan Ekadjaja, A. (2017). Analisis pengaruh leverage terhadap nilai perusahaan dengan kepemilikan manajerial dan arus kas bebas sebagai variabel pemoderasi. Jurnal Ekonomi, 22(1), 164-176.

Mandey, S. R Pangemanan, S. S., dan Pangerapan, S. (2017). Analisis pengaruh insider ownership, leverage, dan profitabilitas terhadap nilai perusahaan pada sektor perusahaan manufaktur dibursa efek indonesia periode tahun 2013-2015. Jurnal EMBA, 5(2), 1463-1473.

Maninda, V. R., dan Agustia, D. (2017). Pengaruh pengungkapan emisi karbon terhadap nilai perusahaan (studi pada perusahaan jepang yang terdaftar dalam japan climate change report 2012-2014). Simposium Nasional Akuntansi, 20(AKMK-6754).

Matsumura, E. M., Prakash, R., dan Vera-Munoz, S. C. (2014). Firm-value effect of carbon emissions and carbon disclosures. The Accounting Review, 89(2), 695-724.

Munawaroh, A., dan Priyadi, M. P. (2014). Pengaruh profitabilitas terhadap nilai perusahaan dengan corporate social responsibility sebagai variabel moderasi. Jurnal Ilmu Dan Riset Akuntansi, 3(4), 1-17.

Novari, P. M., dan Lestari, P. . (2016). Pengaruh ukuran perusahaan, leverage, dan profitabilitas terhadap nilai perusahaan pada sektor properti dan real estate. E-Jurnal Manajemen Unud, 5(9), 5671-5694.

Nugroho, W. C., dan Abdani, F. (2017). Pengaruh profitabilitas, dividend policy, leverage, dan keputusan investasi terhadap nilai perusahaan konstruksi di Bursa Efek Indonesia. ElMuhasaba, 8(1), 104-122.

Nurdiawansyah. (2017). Determinan pengungkapan emisi karbon pada perusahaan manufaktur di indonesia. Tesis, Program Magister Universitas Lampung, Bandar Lampung, Indonesia, Didapat dari http://digilib.unila.ac.id/27553/.

Ogolmagai, N. (2013). Leverage pengaruhnya terhadap nilai perusahaan pada industri manufaktur yang go public di indonesia. Jurnal EMBA, 1(3), 81-89.

Olayinka, A., dan Oluwamayowa. (2014). Corporate environmental disclosure and market value of qoute companies in nigeria. The Business and Management Review, 5(3), 171-184.

Prasetyorini, B. F. (2013). Pengaruh ukuran perusahaan, leverage, price earning ratio, dan profitabilitas terhadap nilai perusahaan. Jurnal Ilmu Manajemen, 1(1), 183-196.

Putra, A. N. D. A., dan Lestari, P. . (2016). Pengaruh kebijakan dividen, likuiditas, profitabilitas, ukuran perusahaan terhadap nilai perusahaan. E-Jurnal Manajemen Udayana, 5(7), 40444070.

Rachmawati, D., dan Pinem, B. D. (2015). Pengaruh profitabilitas, leverage, dan ukuran perusahaan terhadap nilai perusahaan. Equity, 18(1), 1-18.

Riadi, M. (2017). Pengertian, jenis, dan pengukuran nilai perusahaan. Didapat Dari Https://Www.Kajianpustaka.Com/2017/11/Pengertian-Jenis-Dan-Pengukuran-NilaiPerusahaan.Html, 24 Agustus 2019, pukul 13:31 WIB.

Rizqia, D. A., Aisjah, S., dan Sumiati. (2013). Effect of Managerial Ownership, Financial Leverage, Profitability, Firm Size, and Investment Opportunity on Dividend Policy and Firm Value. Research Journal of Finance and Accounting, 4(11), 120-130.

Saka, C., dan Oshika, T. (2014). Disclosure effects, carbon emissions and corporate value. Sustainability Accounting, Management and Policy Journal, 5(1), 22-45.

Sampurna, D. S., dan Sari, M. N. (2018). Pengaruh keputusan investasi, kebijakan dividen, dan profitabilitas terhadap nilai perusahaan. Journal Akuntansi Bisnis, 4(1), 103-119. 
Sari, I. P., dan Abundanti, N. (2014). Pengaruh pertumbuhan perusahaan dan leverage terhadap profitabilitas dan nilai perusahaan. E-Jurnal Manajemen Unud, 3(5), 1427-1441.

Septariani, D. (2017). Pengaruh kebijakan dividen dan kebijakan hutang terhadap nilai perusahaan. Journal of Applied Business and Economics, 3(3), 183-195.

Sitanggang, J. P. (2014). Manajemen Keuangan Perusahaan Edisi 2. In Jakarta: Mitra Wacana Media.

Sleiter, N. (2018). Pengaruh profitabilitas terhadap nilai perusahaan dengan pengungkapan corporate social responsibility sebagai variabel moderasi. Skripsi, Program Sarjana Universitas Katolik Widya Mandala Surabaya, Surabaya, Indonesia, Didapat dari http://repository.wima.ac.id/15225/.

Sutama, D. R., dan Lisa, E. (2018). Pengaruh leverage dan profitabilitas terhadap nilai perusahaan. Jurnal Sains Manajemen dan Akuntansi, 10(1), 21-39.

Tanjung, M. F. (2019). Pengaruh pengungkapan modal intelektual, profitabiliats, dan kebijakan hutang terhadap nilai perusahaan. Skripsi, Program Sarjana Universitas Katolik Widya Mandala Surabaya, Surabaya, Indonesia, Didapat dari http://repository.wima.ac.id/18917/.

Thaib, I., dan Dewantoro, A. (2017). Pengaruh profitabilitas dan likuiditas terhadap nilai perusahaan dengan struktur modal sebagai variabel intervening. Jurnal Riset Perbankan Manajemen Dan Akuntansi, 1(1), 25-44.

Wijaya, H. (2018). Pengaruh profitabilitas dan leverage terhadap nilai perusahaan. Skripsi, Program Sarjana Universitas Katolik Widya Mandala Surabaya, Surabaya, Indonesia, Didapat dari http://repository.wima.ac.id/16158/. 